\title{
Dust Accumulation in the Canopy: A Potential Cause of Dental Microwear in Primates
}

\author{
PETER S. UNGAR, MARK F. TEAFORD, KENNETH E. GLANDER, \\ AND ROBERT F. PASTOR \\ Department of Anthropology, University of Arkansas, Fayetteville, \\ Arkansas 72701 (P.S.U.); Department of Cell Biology and Anatomy, \\ The Johns Hopkins University School of Medicine, Baltimore, Maryland \\ 21205 (M.F.T., R.F.P.); Department of Biological Anthropology and \\ Anatomy, Duke University, Durham, North Carolina 27710 (K.E.G.)
}

\begin{abstract}
KEY WORDS Dust accumulation, Dental microwear, Exogenous grit
\end{abstract}

\begin{abstract}
Dental microwear researchers consider exogenous grit or dust to be an important cause of microscopic wear on primate teeth. No study to date has examined the accumulation of such abrasives on foods eaten by primates in the forest. This investigation introduces a method to collect dust at various heights in the canopy. Results from dust collection studies conducted at the primate research stations at Ketambe in Indonesia, and Hacienda La Pacifica in Costa Rica indicate that 1) grit collects throughout the canopy in both open country and tropical rain forest environments; and 2) the sizes and concentrations of dust particles accumulated over a fixed period of time differ depending on site location and season of investigation. These results may hold important implications for the interpretation of microwear on primate teeth. 1995 Wiley-Liss, Inc.
\end{abstract}

Researchers have repeatedly demonstrated that specific diets and ingestive behaviors leave characteristic patterns of microscopic scratches and pits on extant primate teeth (see Teaford, 1994; Ungar, 1992a; for review). Microwear studies can, therefore, likely reveal important information about diet and tooth use of extinct primates. The resolution of this technique is, however, limited by our understanding of microwear formation processes and causal agents.

Several authors have argued that primate dental microwear is formed in large part as the result of contact between teeth and exogenous grit or dust on foods (Covert and Kay, 1981; Kay and Covert, 1983; Lucas, 1994; Peters, 1982; Ungar, 1990, 1994; Walker, 1976; Wallace, 1974). Thus, differences in the types or amounts of grit might affect patterns of microscopic wear on primate teeth. For example, seasonal and ecological zone differences in microwear patterns identified for numerous platyrrhines by Teaford and coauthors (Burnell and Teaford, 1994; Teaford and Glander, 1991; Teaford and Robinson, 1989; Teaford and Runestad, 1992; Teaford et al., 1994) might be related, at least in part, to differences in dust accumulation in the canopy.

Unfortunately, no study has examined dust accumulation with an eye towards understanding dental microwear. While anecdotes abound concerning grit on primate foods, we really do not know how or even whether such grit differs in different seasons or locations, or even whether windborne dust builds up at all on foods taken in the high, closed canopy primary rain forests occupied by many primates today. This paper describes two separate studies of dust collected at primate research stations. Re-

\footnotetext{
Received June 30, 1993; accepted December 29, 1994.

Address reprint requests to Peter $\mathbf{S}$. Ungar, Department of Anthropology, University of Arkansas, Old Mam 330, Fayetteville, AR 72701.
} 
sults suggest that abrasive grit does accumulate on primate foods in both open habitats and closed canopy rain forests. Further, the abundance and properties of dust particles vary by both site and season.

\section{MATERIALS AND METHODS}

These studies involved analysis of grit accumulated under a variety of conditions in habitats occupied by primates with documented microwear patterns. Dust collectors were constructed, exposed at various heights, and then analyzed using a light microscope to identify and document accumulated grit. The studies described here were conducted on dust collected at 1 ) the $\mathrm{Ke}$ tambe Research Center in northern Sumatra, and 2) Hacienda La Pacifica in northwestern Costa Rica. The primates found at each research station have been followed more-or-less continuously for more than 2 decades, and an extensive literature exists on the social and behavioral ecology of the groups studied.

\section{The research sites}

Ketambe is located in northern Sumatra's Gunung Leuser National Park. The study area is mostly primary lowland rain forest (see Rijksen, 1978; and van Schaik and Mirmanto, 1985; for a detailed description) bordered in the north by the Ketambe and Alas Rivers and in the south by mountainous escarpments of the Barison Range. Mean annual rainfall is over $3,200 \mathrm{~mm}$, varying from approximately $200 \mathrm{~mm}$ in January and $\mathrm{Au}$ gust to about $400 \mathrm{~mm}$ in April and November (Schaik, 1986). Seven species of primates are known to inhabit these forests, and dental microwear has been documented for the incisor teeth of Hylobates lar, Macaca fascicularis, Pongo pygmaeus, and Presbytis thomasi.

In contrast, Hacienda La Pacifica is located in the more open, drier location of Guanacaste Province in Costa Rica. The study area at La Pacifica comprises patches of tropical dry forest interspersed with pasture lands (Glander, 1981). Alouatta palliata are the only primates at the site, and their home ranges are generally restricted to one of two different microhabitats: riverine forests or patches of forest isolated from
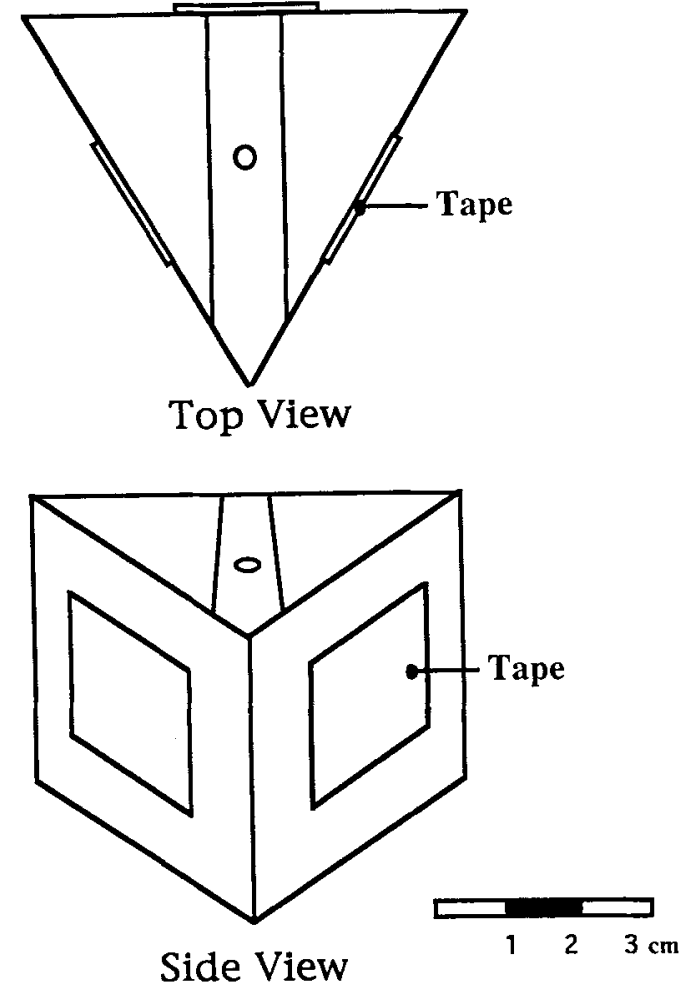

Fig. 1. A dust collector.

the rivers. Moreover, La Pacifica is subject to much more distinct wet and dry seasons than Ketambe, with rainfall varying from only about $1 \mathrm{~mm}$ in January to more than $200 \mathrm{~mm}$ in September, with an average of $1,100 \mathrm{~mm}$ per year.

\section{The dust collectors}

Dust collectors were designed to 1) minimize particle buildup before and after exposure in the forest, 2) facilitate placement in the canopy, and 3) allow sampling from all directions (to minimize wind bias). For the Sumatran study, thin strips of Scotch 3M clear plastic tape were removed from the spool and immediately covered with clean plastic tabs. These strips were then attached to each of three sides of a plastic housing unit constructed with a shaft running vertically through its center (Fig. 1). A thin nylon rope was placed through the axes of ten such dust collectors, which were then raised into the canopy by pulling the free 
end of the rope over a high bough of a tree located in a flat area in the center of the research site. The two ends of the rope were then staked down to secure and stabilize the dust collectors, which were held at $2.9 \mathrm{~m}$ intervals from one to $27.1 \mathrm{~m}$ above the ground. Each tape strip was exposed by removing its plastic tab as the collectors were raised. These collectors were left exposed from 20 to 30 June, 1991 (at the beginning of the dry season), and then covered with clean adhesive labels as they were lowered. Any dust collected in the canopy was trapped between the tape and adhesive label, and could be seen through the clear plastic of the tape.

The Costa Rican study employed a similar technique. Adhesive labels were cut into thin strips and three were attached facing 120 degrees apart on each of several plastic housing units. As with the Sumatran dust study, a thin nylon rope was threaded through the shafts of these dust collectors, which were then exposed as they were hoisted. In this case, collectors were placed at heights of $5.5 \mathrm{~m}$ and $11.5 \mathrm{~m}$, left exposed for 2 to 3 days, and covered with clean plastic tape as they were lowered. The differences in techniques used in the two studies reflect, in part, differences in anticipated rates of saturation of the collectors and differences in the heights of trees in the canopy and foods available to the primates. Six such strings were placed at various locations around La Pacifica; in both the gallery forests lining the Corobici River and in more open woodlands. Dust was sampled at La Pacifica in both February (dry season) and July (rainy season) of 1993.

\section{Data analysis}

The three tapes on each of the collectors were later mounted on microscope slides, and examined using a light microscope. For the Sumatran study, all visible particles (at $\times 250$ magnification) were tallied for ten adjacent $0.1 \mathrm{~mm}^{2}$ fields $\left(=1 \mathrm{~mm}^{2}\right)$ in each slide. An automated procedure was used to quantify the Costa Rican dust sample data. The microscope was attached to an IBM 80486 microcomputer running the Image-1 software package. Five $.2 \mathrm{~mm}^{2}$ fields $(=1$ $\mathrm{mm}^{2}$ ) were selected randomly, and dust particles visible at $\times 200$ magnification were
TABLE 1. Particle density on Sumatran dust collectors

\begin{tabular}{cc}
\hline Height $(\mathrm{m})$ & $\begin{array}{c}\text { Particle density } \\
\text { (per } \text { mm }^{2} \text { per day) }\end{array}$ \\
\hline 1.0 & 6.27 \\
3.9 & 3.80 \\
6.8 & 5.07 \\
9.7 & 4.57 \\
12.6 & 3.17 \\
15.5 & 3.37 \\
18.4 & 3.60 \\
21.3 & 5.83 \\
24.2 & 5.23 \\
27.1 & 2.43 \\
\hline
\end{tabular}

identified by thresholding. Particle density and average diameter were then determined automatically by the computer. For both studies, counts for each of the three tags from each collector were summed, yielding a $3 \mathrm{~mm}^{2}$ sample area at each height for each location and season.

The Costa Rican dust data were analyzed using a three-factor multivariate analysis of variance (MANOVA) without replication. Dust particle size (mean minimum diameter of those particles) and concentration were the variables, and location, season, and height were the categorical factors. This procedure allows assessment of variation (in dust particle size and density) introduced by each factor independent of the others. All data were rank-transformed to mitigate possible violations of assumptions inherent in parametric linear hypothesis models (Conover and Iman, 1981).

\section{RESULTS \\ The study at Ketambe}

The Sumatran dust collectors revealed an average density of 43.3 particles per $\mathrm{mm}^{2}$ for the 10 day sample period, and the presence of microscopic dust throughout the height sequence (Table 1). This indicates an average accumulation of 4.3 particles per $\mathrm{mm}^{2}$ per day at the heights sampled. There is no clear relationship between height in the canopy and amount of dust accumulated.

\section{The study at La Pacifica}

The Costa Rican dust collectors revealed an average count of 87.6 particles per $\mathrm{mm}^{2}$ for the 2 day sampling period, independent of season or location. This indicates an average accumulation of 43.8 particles per $\mathrm{mm}^{2}$ 
TABLE 2. Descriptive statistics for study at La Pacifica ${ }^{1}$

\begin{tabular}{|c|c|c|c|c|c|c|}
\hline \multirow[b]{2}{*}{ Season } & \multicolumn{6}{|c|}{ No. } \\
\hline & 1 & 2 & 3 & 4 & 5 & 6 \\
\hline \multicolumn{7}{|c|}{ I. Height $=5.5 \mathrm{~m}$} \\
\hline Wet & 51.83 & 58.00 & 113.67 & 30.22 & 117.00 & 61.83 \\
\hline Dry & 12.00 & 13.17 & 14.00 & 15.83 & 14.33 & 84.83 \\
\hline \multicolumn{7}{|c|}{ Diameter } \\
\hline Wet & 2.6 & 1.7 & 1.6 & 2.2 & 1.8 & 2.0 \\
\hline Dry & 3.6 & 4.0 & 3.9 & 5.4 & 8.2 & 2.3 \\
\hline \multicolumn{7}{|c|}{ II. Height $=11.5 \mathrm{~m}$} \\
\hline \multicolumn{7}{|c|}{ Density } \\
\hline Wet & 41.33 & 39.45 & 58.17 & 69.00 & 44.67 & 79.00 \\
\hline Dry & 12.67 & 18.17 & 17.33 & 12.50 & 25.50 & 47.00 \\
\hline \multicolumn{7}{|c|}{ Diameter } \\
\hline Wet & 2.2 & 1.9 & 1.7 & 2.0 & 1.7 & 1.7 \\
\hline Dry & 5.3 & 3.6 & 3.6 & 7.6 & 4.1 & 3.3 \\
\hline
\end{tabular}

${ }^{1}$ Density represents number of dust particles accumulated per $\mathrm{mm}^{2}$ per day. Diameter represents the mean minimum diameter of dust particles (in micrometers) accumulated under each set of conditions.

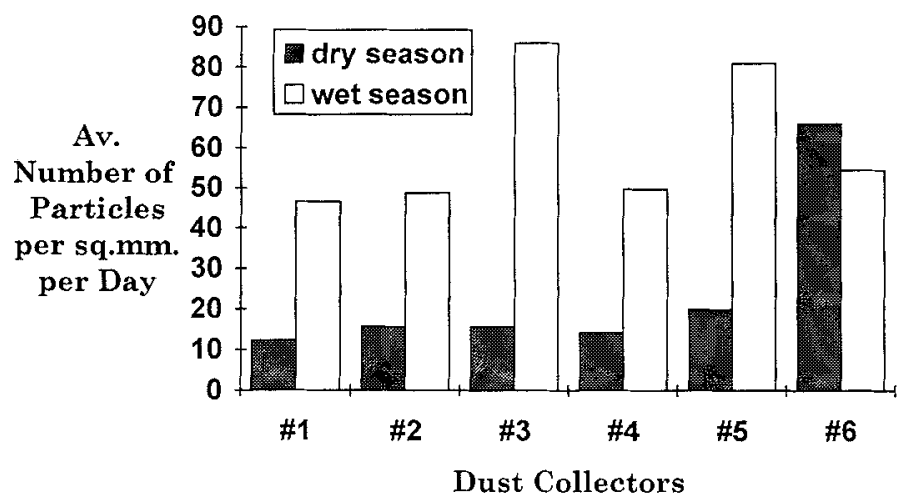

Fig. 2. Seasonal differences in the amount of dust in the canopy at La Pacifica, Costa Rica. This graph presents the average number of particles per $\mathrm{mm}^{2}$ per day of dust collection. Values at $5.5 \mathrm{~m}$ and $11.5 \mathrm{~m}$ are averaged. Wet and dry season concentrations are presented for each of the six locations sampled.

per day at the heights sampled. Dust was evident in both seasons and both heights at all locations. Average particle density and diameter data are presented in Table 2. These data are summarized graphically in Figures 2 and 3 . Results from the statistical analyses are presented in Table 3 . Both the season of collection and the microhabitat at La Pacifica have a significant effect on the number and sizes of dust particles. There are no significant differences in particle sizes and counts between the two heights of collection.

\section{DISCUSSION}

The high, closed canopy and relatively calm eolian currents at Ketambe make this research site well suited for determining whether dust accumulates on primate food sources under the conditions that many forest dwelling primates live. Further, the strong seasonality and ecological zonation at La Pacifica make this study area ideal for assessing the effects of such variables on the buildup of grit on primate foods. Results for each of the studies will be considered separately.

\section{The Ketambe Study}

One initial problem with the eolian transport of soil particles from the ground into the canopy is that currents in closed canopy rain forests are generally not strong enough to dislodge minerals from the surfaces of clay- 


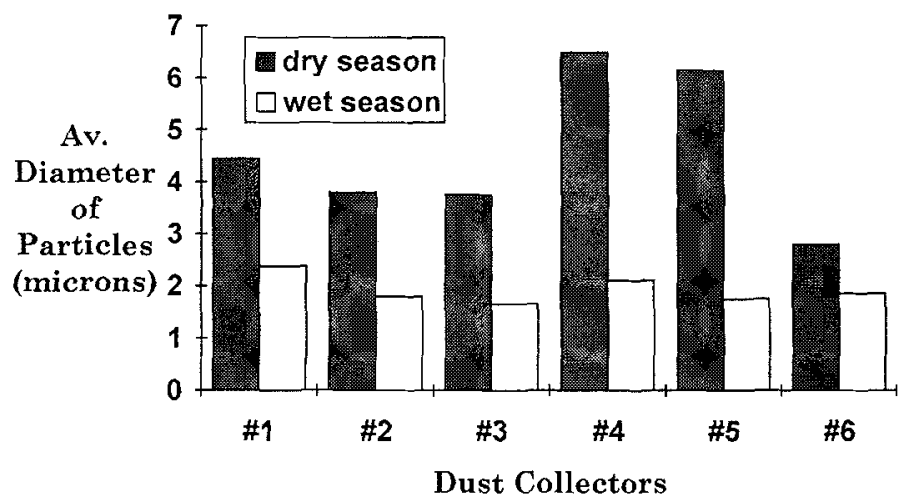

Fig. 3. Seasonal differences in the size of dust in the canopy at La Pacifica, Costa Rica. This graph presents the average diameter of particles (in micrometers) collected at each of the six locations sampled during the wet and dry seasons.

TABLE 3. Statistical test results for study at La Pacifica ${ }^{1}$

\begin{tabular}{lccrrc}
\hline & Wilks' $\lambda$ & Pillai trace & $F$ & $d f$ & $P$ \\
\hline Locale & .628 & .372 & 4,442 & 2,15 & .031 \\
Season & .245 & .755 & 23.138 & 2,15 & .000 \\
Height & .939 & .061 & 0.486 & 2,15 & .624 \\
\hline
\end{tabular}

${ }^{1}$ Wilks' $\lambda$, Pillai Trace, and $F$-test statistics are presented for each effect for the MANOVA employing rank-transformed dust particle concentration and ranked size as the variables.

rich soils (Strahler and Strahler, 1983), and air in the first millimeter above the ground surface is practically still (Press and Siever, 1978). However, once the ground surface is disturbed, for example by passing animals or litterfall hitting the ground, quartz particles may be dislodged and even the slightest air currents can move them or keep them suspended to eventually settle on fruits, leaves or other items consumed by primates in the area.

The implications of this project for the study of dental microwear are clear. Abrasive grit does get into the rain forest canopy. Some of this dust is organic and probably would not scratch tooth enamel, but comparisons with topsoil samples suggest that much of it is inorganic clay from the ground as well. The Al-horizon at Ketambe is a typical tropical rain forest Ultisol (Beek, 1980; Ungar, 1992b). These highly weathered soils are invariably comprised of hard, insoluble quartz and other resistant silicate minerals, such as Kaolinite (Siever, 1957; Burnham, 1985). Because quartz measures 7 on Moh's hardness scale and the apatite crystals that form dental enamel measure 5, teeth would likely be scratched by such particles. The present study shows that these particles are indeed found high in the forest canopy.

\section{The study at La Pacifica}

The results of the study at La Pacifica also confirm that potentially abrasive dust particles are transported into the canopy. Although the techniques for data collection varied between the two studies, it is clear that considerably more dust per day is present under all conditions at La Pacifica than at Ketambe. There were also differences in dust accumulation among the sites and between seasons at La Pacifica. For example, fewer particles were collected but average particle size was larger during the dry season.

The implications of these results for microwear studies are not yet entirely clear. Howler monkey tooth impressions collected in the dry season generally show more microwear and a faster rate of tooth wear than do those collected in the wet season (Teaford et al., 1994). This is the exact opposite of 
what one would expect given the results of this study. In other words, how could less dust yield more monkey tooth wear in the dry season? Either something else is causing the wear, or not all the dust particles are sticking to food and/or acting as abrasives. The average particle size differences between wet and dry seasons suggest that the latter may be the more viable alternative. However, until we know more about the actual composition of the dust particles and the foods of the howlers, this can only be suggestive evidence at best.

\section{CONCLUSIONS}

Results of the present studies suggest that dust particles do reach quite high in the canopy. Of equal interest is that dust particle size and density vary by season and that dust concentration varies between habitats. Much of this exogenous grit may contribute to microwear on primate teeth-although further work is necessary to better document this. For example, studies are currently underway (Pastor et al., 1995) using new techniques for the collection of dust samples. These involve the use of portable air pumps sampling precise quantities of air, collecting dust samples on filter membranes with specific pore sizes. New methods of imaging dust, and analysis of individual dust particles, should then allow us to determine what proportion of the dust particles is capable of scratching teeth.

\section{ACKNOWLEDGMENTS}

We thank Michael Nichols and Usman Putra Gayo for their assistance in hoisting the dust collectors into the canopy at Ketambe. We acknowledge the Universitas Nasional in Jakarta for their sponsorship, and the government of Indonesia for permission to conduct research at Ketambe. In addition, we are grateful to Courtney Burnell, John Fleagle, Fred Grine, Charlie Janson, Bill Jungers, Lawrence Martin, Vivian Noble, and Alan Walker for their technical help and comments on aspects of this project. Also, we thank Stephan Schmidheiny and the Board of Directors at Hacienda la Pacifica for permission to work at the site and for their continued support. Data were analyzed using computing facilities in the laboratories of Drs. Fred Grine and Lawrence Martin in the Department of Anthropology at the State University of New York at Stony Brook and at the Duke University Morphometrics Laboratory.

This project was funded by grants from the COSHEN-Pew Foundation to Duke University, the LSB Leakey Foundation (to P.S.U.) and National Science Foundation grants BNS-9009046 (to P.S.U.) and DBC9118876 (to M.F.T. and K.E.G.).

\section{LITERATURE CITED}

Beek CGG van (1980) Een geomorfologische bodemkundige studie van het Gunung Leuser Nationale Park Noord Sumatra, Indonesie. Ph.D. Dissertation, State University of Utrecht.

Burnell CL, and Teaford MF (1994) Dental microwear differs by capture site in live-caught Alouatta from Costa Rica. Am. J. Phys. Anthropol. Suppl. 18:62.

Burnham CP (1985) The forest environment soils. In TC Whitmore (ed.): Tropical Rainforests of the Far East, 2nd ed. Oxford: Oxford University Press, pp. 137-154.

Covert HH, and Kay RF (1981) Dental microwear and diet: implications for determining the feeding behavior of extinct primates, with a comment on the dietary pattern of Sivapithecus. Am. J. Phys. Anthropol. 55: 331-336.

Conover WJ, and Iman RL (1981) Rank transformations as a bridge between parametric and nonparametric statistics. Am. Statistician 35:124-129.

Glander K (1981) Feeding patterns in mantled howling monkeys. In A Kamil and TD Sargent (eds.): Foraging Behavior: Ecological, Ethological, and Psychological Approaches. New York: Garland Press, pp. 231-259.

Kay RF, and Covert HH (1983) True grit: a microwear experiment. Am. J. Phys. Anthropol. 61:33-38.

Lucas PW (1994) Fundamental physical properties of fruits and seeds in primate diets. Proceedings of the XIIIth Congress of the Int. Primatol. Soc.

Pastor RF, Teaford MF, and Glander KE (1995) Method for collecting and analyzing airborne abrasive particles from neotropical forests. Am. J. Phys. Anthropol. Suppl. 20:168.

Peters CR (1982) Electron-optical microscopic study of incipient dental microdamage from experimental seed and bone crushing. Am. J. Phys. Anthropol. 57:283301.

Press F, and Siever R (1978) Earth, 2nd ed. San Fransisco: W.H. Freeman and Company.

Rijksen HD (1978) A Field Study on Sumatran Orangutans: Ecology, Behavior, and Conservation. Wagening: $H$. Veenman and Zonig.

Schaik CP van (1986) Phenological changes in a Sumatran rainforest. Biotropica 17:196-205.

Schaik CP van, and Mirmanto E (1985) Spatial variation in the structure and litterfall of a Sumatran rain forest. Biotropica 17:196-205. 
Siever R (1957) The silica budget in the sedimentary cycle. Am. Mineral. 42:821-841.

Strahler AN, and Strahler AH (1983) Modern Physical Geography, 2nd ed. New York: John Wiley and Sons.

Teaford MF (1994) Dental microwear and dental function. Evol. Anthropol. 3:17-30.

Teaford MF, and Glander KE (1991) Dental microwear in live, wild-trapped Alouatta palliata from Costa Rica. Am. J. Phys. Anthropol. 85:313-319.

Teaford MF, Pastor RF, Glander KE, and Ungar PS (1994) Dental microwear and diet: Costa Rican $A l$ ouatta revisited. Am. J. Phys. Anthropol. Suppl. 18: 194.

Teaford MF, and Robinson JG (1989) Seasonal or ecological differences in diet and molar microwear in Cebus nigrivittatus. Am. J. Phys. Anthropol. 80:391-401.

Teaford MF, and Runestad JA (1992) Dental microwear and diet in Venezuelan primates. Am. J. Phys. Anthropol. 88:347-364.

Ungar PS (1990) Incisor microwear and feeding behavior in Alouatta seniculus and Cebus olivaceus. Am. J. Primatol. 20:43-50.

Ungar PS (1992a) Dental evidence for diet in primates. Anthropol. Közl. 34:141-155.

Ungar PS (1992b) Incisor microwear and feeding behavior of four Sumatran anthropoids. Ph.D. dissertation, State University of New York at Stony Brook.

Ungar PS (1994) Incisor microwear of Sumatran anthropoid primates. Am. J. Phys. Anthropol. 94:339-363.

Walker PL (1976) Wear striations on the incisors of cercopithecoid monkeys as an index of diet and habitat preference. Am. J. Phys. Anthropol. 45:299-308.

Wallace JA (1974) Approximal grooving of teeth. Am. J. Phys. Anthropol. 40:285-290. 